\title{
CELL DENSITY-CORRELATED INDUCTION OF PYRUVATE DECARBOXYLASE UNDER AEROBIC CONDITIONS IN THE YEAST PICHIA STIPITIS*
}

\author{
M. MERgLeR and U. KLINNER** \\ RWTH, Institut für Biologie IV (Mikrobiologie), Lehr- und Forschungsgebiet Angewandte \\ Mikrobiologie, Worringer Weg, 52056 Aachen, Germany
}

(Received: August 31, 2000; accepted: October 5, 2000)

\begin{abstract}
During the aerobic batch cultivation of $P$. stipitis CBS 5776 with glucose, pyruvate decarboxylase was activated in a cell number-correlated manner. Activation started when a cell number between $7 \times 10^{7}$ and $1 \times 10^{8}$ cells $\mathrm{ml}^{-1}$ was reached and the enzyme activity increased during further cultivation. This induction might have been triggered either by an unknown quorum sensing system or by a shortage of cytoplasmic acetyl-CoA.
\end{abstract}

Keywords: Pyruvate decarboxylase - Pichia stipitis - aerobic activity

\section{INTRODUCTION}

P. stipitis exhibits a property uncommon among yeasts: the alcoholic fermentation of xylose [7]. Moreover, the yeast has some genetic and physiological properties that are different from those of Saccharomyces cerevisiae. In earlier experiments, various peculiarities of the genetic system were elucidated by means of a genetic analysis of parasexual hybrids obtained by protoplast fusion [9].

One interesting physiological feature is the induction mechanism of the fermentative enzymes in P. stipitis. During liquid batch cultivation with the usual sugar concentrations ( $2 \%$ or $3 \%$ of glucose or xylose), vigorous activities of both pyruvate decarboxylase (PDC) and alcohol dehydrogenase (ADH) are induced by hypoxic conditions (oxygen concentration $<1 \%$ ). Activities of up to $0.7 \mathrm{U} / \mathrm{mg}$ protein (ADH) were reached, apparently triggered by the oxygen shortage [10-12].

Moreover, during the logarithmic phase of aerobic cultivation ADH and PDC activities are induced by a shift from fully aerobic conditions to an oxygen concentration of $20 \%$ [10]. During continued cultivation at $20 \%$ oxygen concentration, the activities of both enzymes increase up to $0.6 \mathrm{U} / \mathrm{mg}$ protein (PDC) and $0.4 \mathrm{U} / \mathrm{mg}$ protein $(\mathrm{ADH})$. This is noteworthy because well-characterized oxygen-dependent sys-

\footnotetext{
*Dedicated to Professor Lajos Ferenczy on the occasion of his 70th birthday.

**Corresponding author; e-mail: ulrich.klinner@rwth-aachen.de
} 
tems of bacteria, of the yeast $S$. cerevisiae or of mammals respond to hypoxic conditions only if the oxygen concentration is lower than $3 \mu \mathrm{M}$ [2]. A concentration of $20 \% \mathrm{O}_{2}$ corresponds to approximately $60 \mu \mathrm{M}$ and is too high to act as a trigger of the known hypoxia-induced system. Therefore, it can be postulated that an unknown low - affinity oxygen - dependent regulation mechanism of PDC and ADH exists in $P$. stipitis.

In this context, we were interested in further characterization of the conditions leading to PDC activition. To our surprise, we measured a weak but reproducible activation of PDC in the cells of $P$. stipitis during growth under fully aerobic conditions (oxygen concentration $>80 \%$ ).

\section{MATERIALS AND METHODS}

The strain P. stipitis CBS 5776 was kindly provided by C. P. Kurtzmann. The cells were grown in a mineral salt medium (PMM) composed according to [3]. Additionally, the medium contained $3 \%$ glucose as carbon source.

Cells were cultivated in a Braun Biostat E 5 fermenter containing 51 of medium at a temperature of $25^{\circ} \mathrm{C}$. The $\mathrm{pH}$ was held constant at 5.0 by using $1 \mathrm{M} \mathrm{NaOH}$. The oxygen concentration was measured and controlled by means of a $\mathrm{pO}_{2}$-electrode (Fa. Ingold). The fermenter was aerated with a constant air stream (1 vvm). Aerobic conditions were maintained in a regulated or in an unregulated way. During fermentation with an unregulated oxygen concentration, the cultures were stirred at a rotary speed of $400 \mathrm{rpm}$. Due to the increasing cell number, the oxygen concentration decreased from $100 \%$ at the start to between 94 and $82 \%$ during the stationary phase. Under regulated oxygen conditions, the oxygen concentration was controlled by the $\mathrm{pO}_{2^{-}}$ electrode and the decrease in the oxygen level was compensated by an increased of the rotary speed up to $700 \mathrm{rpm}$.

The yeasts were precultivated in $100 \mathrm{ml}$ of PMM in Fernbach flasks $\left(28{ }^{\circ} \mathrm{C}, 200\right.$ $\mathrm{rpm})$. The fermenter was inoculated with $50 \mathrm{ml}$ of a preculture containing $1 \times 10^{8}$ cells $\mathrm{ml}^{-1}$.

For the enzyme assay, samples of $100 \mathrm{ml}$ of culture medium were taken and transferred immediately into ice-cooled narrow plastic tubes. Crude extracts were prepared as previously described [10]. The extract buffer contained the protease inhibitors phenylmethanesulfonyl fluoride, leupeptin and pepstatin A. PDC and ADH activities were determined according to [1] and protein contents by using the Lowry method. Cell numbers were calculated from determinations of $\mathrm{OD}_{623}$. An OD of 0.1 corresponded to $1 \times 10^{7}$ cells $\mathrm{ml}^{-1}$. Ethanol formation was detected by HPLC with an Aminex Fermentation Monitoring column (Bio-Rad, Hercules, CA), using an RI detector (Melz). 


\section{RESULTS AND DISCUSSION}

Experiments were performed with cultures having a relatively large volume in order to avoid oxygen limitation and to obtain sufficient cell meterial for the determination of enzymatic activities. Figure 1 depicts the growth kinetics in three independent cultivation experiments. In these experiments, the oxygen concentration was unregulated (see Methods). The cultures were started with a cell number of $1 \times 10^{6} \mathrm{ml}^{-1}$. After overnight cultivation, a density of about $3 \times 10^{7}$ cells ml$^{-1}$ was obtained. After $20 \mathrm{~h}$, the cultures left the log phase and entered the stationary phase. The growth rate during the logarithmic phase was $\mu=0.32 \mathrm{~h}^{-1}$ and, accordingly, the generation time was $130 \mathrm{~min}$. The cell yield amounted to $7 \times 10^{8} \mathrm{ml}^{-1}$. These parameters demonstrate that the growth conditions were nearly optimal and not restricted by any shortage of a medium component (up to the transition to the stationary phase).

Beginning from a cultivation time of $12 \mathrm{~h}$, we determined the PDC activities of cell homogenates. Unexpectedly, between 14 and $15 \mathrm{~h}$ of cultivation we measured a small activity that increased with progressive cultivation time. In Fig. 2, the data of seven independent experiments are combined. Activation started as a function of the cell density. It became measurable at cell numbers between $7 \times 10^{7}$ and $1 \times 10^{8} \mathrm{ml}^{-1}$. Activation was not artifical and did not occur due to inadequate protein extraction from small cell numbers, because similar amounts of protein were extracted from the cells before and after induction. The question arises as to what might have triggered this induction. Obviously, it was not caused by a hypoxic oxygen shortage. Induction could be due to the exhaustion of any nutrient component. However, neither duplication nor bisection of the PMM components had any influence on the cell density at PDC induction.

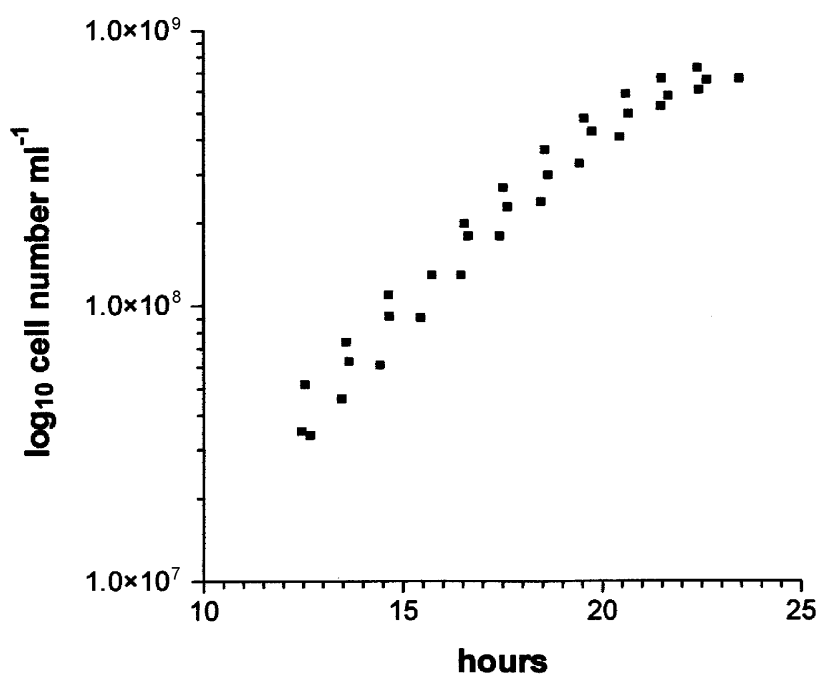

Fig. 1. Growth of P. stipitis CBS 5776 in aerobic liquid culture (data from three experiments) 


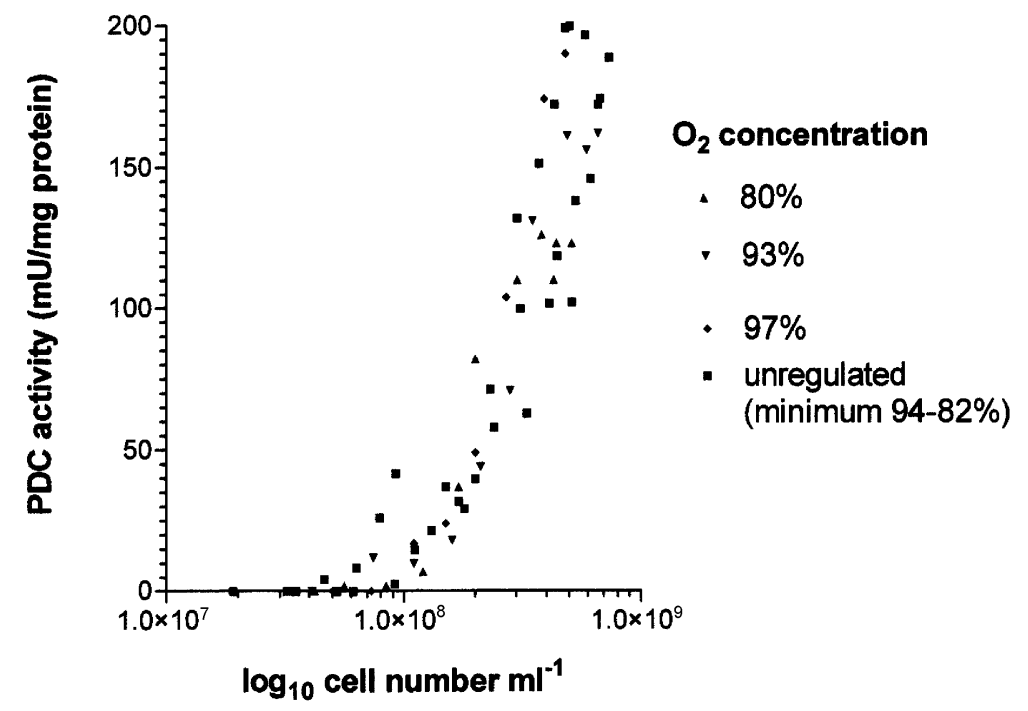

Fig. 2. PDC activity during the aerobic growth of $P$. stipitis CBS 5776 (data from seven experiments)

Induction could be connected with a quorum sensing system [6], as is known for a number of bacteria, but which has not been previously described for eukaryotes. Many bacteria produce small molecules constitutively; these are autoinducers (homoserin lactones) that are able to permeate the cell envelopes without limitation. If their concentration in a growing culture exceeds a certain limit, a number of processes are induced, such as the excretion of exoenzymes or antibiotics, or the expression of bioluminescence components. To indicate a possible autoinduction, P. stipitis $\mathbf{5 7 7 6}$ was recultivated in a recycled culture fluid that had been supplemented with fresh nutrients. No PDC induction was observed at cell densities lower than $7 \times 10^{7}$ cells $\mathrm{ml}^{-1}$. It is possible that the potential inducer was unstable and accumulated only transiently. The $\mathrm{NO}^{\circ}$ radical could be such an inducer. A possible signal function of this molecule in the yeast Candida tropicalis has been described [13].

Primarily, PDC activity is necessary for yeast cells during alcoholic fermentation, i.e. if they use acetaldehyde as an electron acceptor and regenerate NAD by the activity of ADH. According to recent knowledge, this is the case in P. stipitis only under oxygen-limited conditions (see Introduction). Yeasts such as $S$. cerevisiae display alcoholic fermentation even under aerobic conditions and are therefore named Crabtree-positive. In our experiments, ADH activity could not be detected reproducibly in the cell homogenates of P. stipitis. Moreover, ethanol was not detectable in the cultivation medium either. The reason could be that under aerobic conditions PDC is not expressed to participate in alcoholic fermentation.

A second physiological function of PDC has been demonstrated in S. cerevisiae. Together with acetaldehyde dehydrogenase and acetyl-CoA synthetase, it is also 
responsible for the cytoplasmic supply of acetyl-CoA [4,5]. This compound is indispensable for the biosynthesis of lipids and lysine in the cytoplasm, and cannot be transported from the mitochondria to this compartment. Therefore, $\mathrm{Pdc}^{-}$mutants of S. cerevisiae can grow with usual rates only for a short time without acetate supplementation.

It is also possible that in P. stipitis PDC activity is necessary for the supply of cytoplasmic acetyl-CoA. PDC is perhaps induced only if the acetate reserve that the cells have formed during precultivation is exhausted. Cultivation experiments with acetic acid added to the cultivation fluid are now in progress.

Two PDC genes of $P$. stipitis have been described so far [8]. Molecular biological approaches such as gene disruption, expression studies by RT-PCR and utilization of reporter genes for the examination of aerobic PDC activation will be applied in future.

\section{ACKNOWLEDGEMENT}

We thank Ulrike Schmitt for linguistic advice.

\section{REFERENCES}

1. Bergmeyer, H. U. (1977) Methoden der enzymatischen Analyse. Verlag Chemie, Weinheim.

2. Bunn, H. F., Poyton, R. O. (1996) Oxygen sensing and molecular adaptation to hypoxia. Physiol. Rev. 76, 839-885

3. Dellweg, H., Rizzi, M., Methner, H., Debus, D. (1984) Xylose fermentation by yeasts, comparison of Pachysolen tannophilus and Pichia stipitis. Biotechnol. Lett. 6, 395-400.

4. Flikweert, M. T., van der Zanden, L., Janssen, W. M. T. M., de Steensma, H. Y., van Dijken, J. P., Pronk, J. T. (1996) Pyruvate decarboxylase: An indispensable enzyme for growth of Saccharomyces cerevisiae on glucose. Yeast 12, 247-257.

5. Flikweert, M. T., de Swaaf, M., van Dijken, J. P., Pronk, J. T. (1999) Growth requirements of pyruvate-decarboxylase-negative Saccharomyces cerevisiae. FEMS Microbiol. Lett. 174, 73-79.

6. Fuqua, W. C., Winans, S. C., Greenberg, E. P. (1994) Quorum sensing in bacteria: the luxR-luxI family of cell density-responsive transcriptional regulators. J. Bacteriol. 176, 269-275.

7. Hahn-Hägerdal, B. (1996) Ethanolic fermentation of lignocellulose hydrolysates. Appl. Biochem. Biotechnol. 57, 195-199.

8. Lu, P., Davis, B. P., Jeffries, T. W. (1998) Cloning and characterization of two pyruvate decarboxylase genes from Pichia stipitis CBS 6054. Appl. Environ. Microbiol. 64, 94-97.

9. Melake, T., Passoth, V., Klinner, U. (1996) Characterization of the genetic system of the xylose-fermenting yeast Pichia stipitis. Curr. Microbiol. 33, 237-242.

10. Passoth, V., Zimmermann, M., Klinner, U. (1996) Peculiarities of the regulation of fermentation and respiration in the Crabtree-negative, xylose-fermenting yeast Pichia stipitis. Appl. Biochem. Biotechnol. 57, 201-212.

11. Passoth, V., Schäfer, B., Liebel, B., Weierstall, T., Klinner, U. (1998) Molecular cloning of alcohol dehydrogenase genes of the yeast Pichia stipitis and identification of the fermentative ADH. Yeast 14, 1311-1325.

12. Skoog, K., Hahn-Hägerdahl, B. (1990) Effect of oxygenation on xylose fermentation by Pichia stipitis. Appl. Environ. Microbiol. 56, 3389-3394.

13. Wilken, M., Huchzermeyer, B. (1999) Suppression of mycelia formation by NO produced endogenously in Candida tropicalis. Eur. J. Cell Biol. 78, 209-213. 
